\title{
The Deontic \& the Epistemic in Egyptian \& Jordanian Obituaries: A Comparative/Contrastive Study of Religious Minorities Linguistic Expression
}

\author{
Dr. Ahmed Abdel Azim ElShiekh \\ Alexandria University, Egypt \\ Currently: An Associate Professor of Linguistics \& Translation \\ Zarqa University, P.O. Box: 132014, Zarqa University, 13132 Zarqa, Jordan \\ E-mail: shishuj@gmail.com
}

Received: July 22, 2011

Accepted: August 15, 2011

Published: February 1, 2012

doi:10.5539/ass.v8n2p135

URL: http://dx.doi.org/10.5539/ass.v8n2p135

\begin{abstract}
To start with, obituaries are not simply frozen registers that over the years have become conventionalized forms of language use by the press institution. The choice of the particular obituary to be published basically depends on the personal/individual choices of the individual advertiser.

The present research studies the differences \& similarities in obituaries made by Muslims and Christians in Egypt and Jordan. The Objective of the research is to explore the linguistic expression of religious minorities that would in turn reflect, whether intentionally or unintentionally, the cultural features marking such minorities as well as the relation between these minorities and the larger communities, basically of Muslims in both Egypt \& Jordan.

The researcher aims at exploring not only the differences between Christian versus Muslim obituaries, but also the differences between the case with Egyptian Christians on the one hand and Jordanian ones on the other hand, taking into consideration the cultural, social and political associations in the two situations.
\end{abstract}

Keywords: Obituaries, Christian, Muslim, Egyptian, Jordanian, Religious minorities, Deontic, Epistemic

\section{Introduction, Objectives \& Hypothesis of the Research}

The very title of this research dictates the way the researcher should start on the subject. First, a definition of what is meant by the "Deontic" and the "epistemic" has to be provided. It may also be equally important to point out the growing interest in the study of obituaries and its significance in discourse analysis in general. Then, there comes the identification of the scope of the present research and the justifications for the choice of the two daily newspapers dealt with in this research as representative of the phenomenon under study. It would have also been extremely useful to review literature on Egyptian versus Jordanian obituaries as representative of religious groups, yet, unfortunately, the researcher has been totally unable to reach any previous research work on the topic in question. Instead, more general stuff on obituaries was reviewed.

\subsection{Objectives of the Research}

The present research studies the differences \& similarities in obituaries made by Muslims and Christians in Egypt and Jordan. The Objective of the research is to explore the linguistic expression of religious minorities that would in turn reflect, whether intentionally or unintentionally, the cultural features marking such minorities as well as the relation between these minorities and the larger communities, basically of Muslims in both Egypt \& Jordan.

The researcher aims at exploring not only the differences between Christian versus Muslim obituaries, but also the differences between the case with Egyptian Christians on the one hand and Jordanian ones on the other hand, taking into consideration the cultural, social and political associations in the two situations. 


\subsection{Hypotheses of the Research}

To start with, obituaries are not simply frozen registers that over the years have become conventionalized forms of language use by the press institution. The choice of the particular obituary to be published basically depends on the personal/individual choices of the individual advertiser. In fact, obituaries are not texts that are produced by the editorial board of the daily newspapers in which they appear. Instead, they are developed and designed by the individual members of the two language communities investigated. The expressions used by the author are essentially Biblical or Koranic verses by nature, since the advertisers are either Muslims or Christians. Yet, the choice of one verse rather than another is quite significant. It is only normal that a Christian shall resort to the use of a Biblical verse whereas a Muslim is apt to employ a Koranic one. The actual Biblical or Koranic verse to be used is totally up to the individual advertiser to choose and, consequently, does reflect his/her attitude. In other words, the researcher starts this research with a hypothesis that obituaries may and most probably shall reflect significant differences not only between Muslim versus Christian obituaries per se, but more important still between Christian Egyptian obituaries on the one hand and Christian Jordanian ones on the other hand. Such significant differences if and only when proved reflect equally significant differences between the relationship between Jordanian Christians and Muslims in contrast to the relation between Christian and Muslim Egyptians. Thus, obituaries are dealt with in this research not simply as code markers of the global Christian and Muslim communities; they are the linguistic expression of a particular religious community in one particular place and at one particular time. The individual advertiser may not be responsible for the choice of the particular font to be used, but is certainly responsible for the font size, the place where the obituary shall appear, and, first of and above all, for the particular lexical items used including the Koranic and/or Biblical verses used if any. Such responsibility is then translated into the money paid to the newspaper in question in return for the obituary to be published.

\subsection{Scope \& Data of the Research}

The researcher has chosen two major and highly conservative newspapers as representative of Christian and/or Muslim obituaries in Egypt and Jordan, viz. the Egyptian Al-Ahram daily newspaper and the Jordanian Rai daily newspaper over the last week in 2008.

The researcher set out to study all the obituaries and/or death notes published in the two papers in question over the specified period of time, yet, then, for purely practical reasons, the researcher confined his analysis and, hence findings, to the first fifty obituaries in each of the two newspapers, disregarding or rather excluding multiple obituaries on one and the same person. The choice of that particular week rather than any other is, naturally, quite random. There is nothing special about that particular week, and, therefore, the sample of obituaries discussed may be fairly regarded as quite representative rather than simply authentic.

\subsection{Method and Tools of the Research}

In this paper, the researcher adopts a statistical/analytical approach. Simple statistics of the data under study are first presented, and then an attempt at analyzing the findings is made by the researcher, based on semantic as well sociolinguistic considerations.

It is to be pointed out in this respect that some variations of the same expression, involving only a change in the use of definite versus indefinite article and/or the use of partial synonym that is fully synonymous in the context of the given obituary were for procedural convenience dealt with as one and the same epistemic and/or deontic expression.

In such a study, a single occurrence of one expression or one verse as such is hardly regarded as significantly relevant to the objectives of the research. Such single occurrences are bound to be unrepresentative even though they are fully authentic.

\subsection{The Deontic \& the Epistemic}

The two terms Deontic (Note 1) and Epistemic (Note 2) are used here with reference to their main functions in the study of modality and modal verbs, particularly in Germanic languages such as English, German and Dutch.

Both terms are quite commonly used in the study of modality as such, with particular reference to modal verbs in Germanic languages (Note 3).

\subsection{Obituaries}

An obituary is "a notice of a person's death usually with a short biographical account" (Merriam-Webster's $11^{\text {th }}$ Collegiate Dictionary, version 3.1, Electronic version). The word originally comes from Medieval Latin obituarium, from Latin obitus meaning death (Date: 1738) (Note 4). 
The interest in the study of obituaries as a linguistic expression of social attitudes and cultural characteristics of a given community has recently culminated in the publication of Bridget Fowler's book The Obituary as Collective Memory (2007). The book focuses on how societies remember. The author makes great use of the theories of Pierre Bordieu, arguing that obituaries are one important component in society's collective memory. The book is certainly a rich source of information where it comes to the literature on the historical and quantitative studies of the obituary as collective memory as well as the historical sociology of death.

Another recent instance is the research paper entitled "The visual stance of public life: A multimodal analysis of Yasser Arafat's obituaries" by Isabel Corona, presented at the XXVII AESLA International Conference.

Obituaries are not only supposed to reflect the way societies react to the death of their dear ones, but it has been also maintained that they even shape "how societies remember". In other words, they help shape the society's collective memory in one way rather than the other, instead of only depicting it. To quote Paul Connerton, the "Control of a society's memory largely conditions the hierarchy of power" (How Societies Remember, 1989, p. 1)

When an authoritarian power wants to deprive its citizens of social memory "it uses the method of organised forgetting" - some offer "the struggle of their memory against forced forgetting".

A case in point is the findings that a study of samples of obituaries in 1900, 1948, 2000-1 The Times; 2000-1 The Guardian, The Independent and Daily Telegraph and 2000-1 Le Monde (France) and New York Times have revealed that manual workers, for instance, are virtually unseen in the obituaries studied. And, whereas this might be predicted or at least it was even found that there was very little trace of certain middle class occupations such as schoolteachers or social-workers.

\section{The Deontic \& the Epistemic in Egyptian \& Jordanian Obituaries:}

The two terms are used in this research with a rather general sense relating to stating a particular proposition with varying degrees of certitude (epistemic) and to permissibility, duty and thus wishing mercy for the deceased and/or praying for the salvation of the soul and patience and endurance for the relatives of the dead person (Deontic).

It must be admitted that the use of the two terms in this research, therefore, is, at least, slightly untraditional. The researcher, then, distinguishes between prayers \& supplications as Deontic versus declarative propositions as Epistemic. The rationale is that epistemic expressions per se reflect self-confidence and a strong dogmatic attitude, while deontic ones may indicate a less solid stance and/or a more submissive one. The hypothesis is that if a significant difference is found in the use of epistemic versus deontic expressions between Christian obituaries on the one hand and Muslim ones on the other hand, such a difference may as well be indicative of a significant difference between Christian and Muslim attitudes. Linguistic differences usually mark cultural, social and religious ones. Furthermore, if this applies to Christian and Muslim obituaries in Ahram and Rai alike, then it may be reasonable to refer the difference to the different nature of each of the two religions, viz., Christianity and Islam. If, however, the sharp contrast between the two sets of obituaries is confined to the Egyptian and or Jordanian obituaries alone, then there has to be another reason and or justification for the presence of such a phenomenon that does not simply reside in the nature of each faith as such.

\subsection{Deontic Expressions}

The following expressions have been classified by the researcher as possibly deontic expressions.

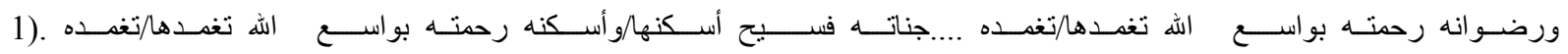
literally meaning May God have mercy on him/her and accept him/her in heaven

2). Literally meaning may God spare you seeing any harm befalling your dearest ones.

The above cited expressions share the supplicatory nature and have been found in both newspapers.

\subsection{Epistemic Expressions}

The following expressions have been classified by the researcher as possibly epistemic ones.

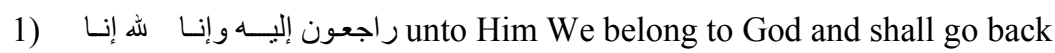

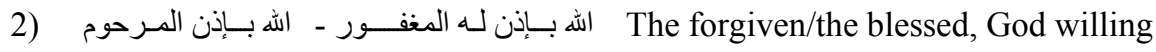

3) A virtuous man/woman deceased

4) القيامــة رجاء على رقدت/رقد 
5) الســـــ Moved to the heavenly glories

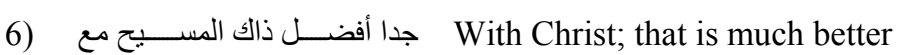

Most of these expressions have been found in both Ahram and Rai too. The only two exceptions are - نعي فاضل whose use was confined to the Jordanian newspaper as well as مع المسيح ذالك أفضل جدا which only occurs in the Egyptian newspaper.

\subsection{Biblical \& Koranic Verses in Egyptian \& Jordanian Obituaries}

There have been quite a few occurrences of Biblical and Koranic verses in the sample obituaries under study, among which the most commonly used, are من آمن بي وإن مات فسيحيى (and whoever lives and believes in me will never die) and الرب أعطى والرب أخذ فليكن اسم الرب مباركا (The Lord hath given and the Lord hath taken, blessed be

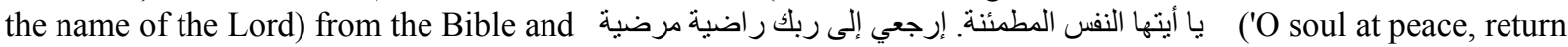
unto thy Lord, well-pleased, well-pleasing!) with فادخلي في عبادي وادخلي جنتي الى رني (Enter thou among My servants! Enter thou My Paradise!)as an optional additional quote from the Koran only in some obituaries.

\section{Findings \& Discussion}

A few observations have been made by the researcher on comparing and contrasting (1) the obituaries made by Muslim versus those made by Christian advertisers in each of the Rai and Ahram newspapers, (2), Jordanian versus Egyptian obituaries as represented by the obituaries in the sample under study, and, (3) finally, exploring the differences, if any, between the relation of Christian obituaries to the Muslim ones in the Jordanian Rai as compared and contrasted with the relation of Christian and Muslim obituaries in the Egyptian Ahram newspaper.

At this point of the research, a quick look at the use of deontic expression in both Rai and Ahram. May be quite helpful.

\subsection{Deontic Expressions}

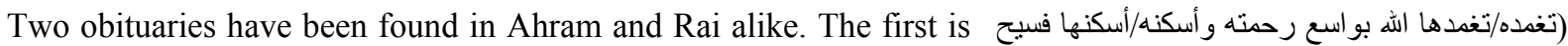
جناته 28 times in the Rai newspaper and 22 times in Ahram with reference to Muslim advertisers.

Another one that was also common to Muslim obituaries in both newspapers is لا أراكم الله مكرو ها في عزيز لايكم)). It occurred 8 times in the Jordanian newspaper and 11 times in the Egyptian one.

In other words, the first obituary occurs in 52.94 percent of the Jordanian Rai obituaries and in 59.45 percent of the Egyptian ones. The difference between the two cases is only less than 7 percent, which is relatively insignificant. The same thing may be fairly said of the second obituary, which occurs in 23.52 percent of the Rai Muslim obituaries and 29.72 of the Ahram ones, with a minor difference between the two representing only less than 6 percent. (See Tables $1 \& 2$ in the appendix)

The discrepancy, however, reveals itself in the distribution of these two obituaries among Muslim and Christian advertisers.

In the case of (تغده/تغد ها الله بو اسع رحمته و أسكنه/أسكنها فسيح جناته - .... بواسع رحمته ورضوانه)

It was also used by 10 out of 16 Christian advertisers in the Rai ones, but by no Christians at all in Ahram out of the 13 obituaries in the sample. Thus, the percentage of its occurrence within the Christian obituaries in the Rai amounts to 62.50 while it is non-existent among Christian obituaries in the Ahram newspapers. It is also worth noting that the difference in the percentage of occurrence of this obituary among Muslim versus Christian obituaries in the Jordanian newspaper is also rather insignificant; only less than 10 percent.

As for the second obituary لا أراكم اله مكروها في (عزيز لديكم), it was used by 5 Christian advertisers in Rai, amounting to 31.25 percent, but by no Christians at all in Ahram. It is worth noting again here that the difference in the rate of occurrence between the Muslim obituaries in the Rai on the one hand and the Christian ones in the same newspaper on the other hand is less than 8 percent, while the occurrence of the same obituary as used by Muslim advertisers in Ahram is 29.72 contrasted with a zero occurrence among Christian advertisers in the same newspaper.

All in all, then, the similarity in the use of the above mentioned deontic expressions in Muslim obituaries Rai versus Muslim ones in Ahram amounts to 79.13 percent with reference to the first obituary (... تغدم) and 89.04 percent in the second one (لا أراكم ... The rate of the common use of the same expressions between Christian and Muslim obituaries in Rai is 84.70 percent in the first and 75.26 percent in the case of the latter. 
A striking difference then only manifests itself in the contrast between the use of the two obituaries in Muslim obituaries in Ahram with 29.72 and 59.45 percent successively as opposed to a Zero percent when it comes to the Christian obituaries found in Ahram. (See Table 3 in the appendix)

Another striking difference manifests itself in the fact that there is a zero percent common ground between the use of the two deontic expressions in question in Ahram but between 75 to 84 percent of common use in Rai; the contrast is clear between the status of Christian obituaries in Jordanian newspapers as represented by Rai on the one hand and the status of Christian obituaries in Egyptian newspapers as represented by Ahram. (See Table 4 in the appendix)

\subsection{Implications \& Discussion}

Two more points have to be made in this respect. The first is that the difference does not seem to originate from a difference between the two religions; Islam and Christianity. If it had been the case, there would have been a more or less similar difference between Christian and Muslim obituaries in the Rai newspaper too rather than in the Ahram alone.

Secondly, the first deontic expression (... تغد ) is typically Islamic in nature and style. Indeed, most Muslim fundamentalists even claim that any supplication involving a prayer for mercy on a Christian or Jew is strictly prohibited for Muslims. Some even maintain that a Muslim who does so is no longer a Muslim! Recorded teachings by well known Islamists as well as written statements are cases in point. In the early nineties of the twentieth century, for instance, a big controversy was raised by Egyptian Rosaelyousef weekly magazine on the occasion of Dr Omar Abdel Kafi's preaching in which he actually forbade Muslims from even congratulating their Christian fellow citizens on Christian holidays or else they would be considered infidels themselves! Hence, the fact that Jordanian Christians use deontic expressions implying a supplication to God to have mercy on the souls of their deceased ones, and the fact that it is acceptable in Jordanian media to have such obituaries published in a country where the extreme majority (Over 90 percent according to official statistics) does have its significance. When this is contrasted with the situation in Ahram, the picture may become even clearer. Yet this can wait until we look at the epistemic expressions involved as well (See charts $1 \& 2$ in Appendix 2).

\section{Epistemic Expressions}

In the case of epistemic expressions, in the form of declarative statements, one was exclusively used in Rai, while five others were used by both newspapers in varying degrees though with a significant change in one case (See Table 5 in the appendix).

Thus, (نعي فاضل/ فاضلة) is only used in the Jordanian newspaper. It is used in 76 percent of the total 50 Jordanian obituaries, reflecting a difference between the Jordanian and Egyptian style of death notes writing, and, at the very same time, reinforcing the presence of quite a notable common ground between the Christians and Muslims in the Jordanian community. The expression occurs in 38 obituaries, with 28 Muslim and 12 Christian ones. And, here again, the percentage of occurrence in Christian obituaries represents a 71.42 percent of its occurrence in Muslim ones.

The difference is much clearer between Jordanian and Egyptian obituaries in the case of (المرحوم بإذن الله المغفور له (7) (ابله ) بإبان اله الهرحوم in a few occasions (7 times) but then the advertisers seem to be quite sure, or may be rather too sure of themselves, as they do not resort to the use of الهرحوم in Ahram is also confined to Muslim obituaries. This may be another evidence to the way Islamists in Egypt regard the Christians' right, or rather no right to ask for God's mercy! This expression occurs in 48 Jordanian obituaries with a percentage as high as 96 percent of the total of 50 ones, with 34 out of 34 Muslim ones and 14 out of the 16 Christian obituaries in Rai. The rate of occurrence is, therefore, 100 percent in Muslim and 87.5 in Christian obituaries, with a common ground amounting to 87.5 between the two sets of obituaries advertised by the followers of the two religions in Jordan.

Another epistemic expression which is typically Islamic as it is originally derived fro a Koranic text is (إنا له و إنا (2) إليه راجعون. The expression is originally a Koranic one but it is so often used orally by people condoling the families and close friends of the deceased, especially in Egypt that it almost ceases to be recognized by the average addressors and addressees as one. It occurs 19 times in Ahram, only with Muslim obituaries, with a rate of occurrence amounting to 51.35 percent, while it was only used by 4 Muslim obituaries in Rai, with a relatively limited rate of occurrence that is less than 12.00 percent of the Muslim obituaries in the Jordanian newspaper.

There are three more epistemic expressions that are particularly Christian in nature. Two of these appeared in both newspapers. First, ( رقد/رقدت على رجاء القيامة)appeared 9 times in Rai, with a percentage of 56.25 in relation to 
the 16 Christian obituaries published in the Jordanian newspaper, and only twice in Ahram, with a percentage of 15.38 only. The second one is (انتقل/انتقلت إلى الأمجاد السماوية)), which occurred 7 times in Rai Christian obituaries and only 3 times in Ahram Christian obituaries with a percentage of 43.75 and 23.07 successively.

Finally, there is a typically Christian expression that appears in Ahram, with the highest percentage of occurrence within the realm of Christian obituaries in the Egyptian newspaper, but is totally non-existent in the Jordanian Rai. The expression in question is (مع المسيح ذالك أفضل جدا). It occurs 7 times, thus representing 53.84 percent out of all the 13 Christian obituaries in Ahram. Indeed, this marks the highest frequency rate of occurrence of any epistemic expression in the Christian obituaries in the sample of the present research.

\subsection{Implications \& Discussion}

In the light of the findings above mentioned, one can reconfirm the assumption that the differences between the Muslim obituaries in Ahram on the one hand and the Christian in the same newspaper on the other hand do not necessarily stem from the very nature of each of the two religions involved. After all, most of such differences do not seem to exist at all in the case of Muslim and Christian obituaries in the Jordanian Rai. Hence, the possibility, and maybe even probability, that these differences are due to the nature of the Christians and Muslims themselves in Egypt.

This is further reinforced by the fact the differences between Christian obituaries in Ahram on the one hand and their counterparts in Rai on the other hand are more in number and significance than the differences between Muslim and Christian obituaries in Rai. In fact, the common ground between Christian obituaries in Ahram and in Rai represents only 38.46 percent in relation to the use of epistemic expressions, whereas the similarities between Christian and Muslim Jordanian obituaries in the same area amount to an average of 75 percent.

Finally, the only Christian epistemic expression that is confined to Ahram is the only one that is not simply Christian in nature but also is conceptually unacceptable for Muslims. It reads (مع المسيح ذالك أفضل جدا) which literally means (With Christ; that is much better). It is not only Christian then but exclusive of other faiths; the keyword here is 'Christ'. Muslims do believe in Christ but only as a prophet and a messenger of God, not as the Word and Incarnation of God as in Jesus Christ our Lord. It is no coincidence that the other two typically Christian epistemic expressions which also appear in Rai are much more general in their conceptual value. One states that dying is some kind of a sleep with the hope of resurrection, and the other refers to the travel of the soul to the glories of heavens with both concepts shared by almost all monotheistic religions, especially Islam and Christianity (See Charts $3 \& 4$ in Appendix 2).

It may be no coincidence, then, that the only epistemic expression which is non-existent in Rai is that one that seems to be saying out loud that the advertiser is different from the rest of the community. In turn, this may indicate that whereas the Egyptian Christian has an urge to distinguish himself/herself from his/her Muslim fellow citizens, the Jordanian counterparts do not feel the same way. It may be even maintained that if one leaves out the names and the Koranic and/or Biblical verses most obituaries in the Rai newspaper will be equally readable as Muslim or Christian. In the case of Ahram, it is quite a different situation. One could tell whether a given obituary is Christian or Muslim by casting a quick look at the epistemic and deontic expressions used (See Chart 5 in Appendix 2).

\section{Biblical \& Koranic Verses}

Only few verses have been used by death notes advertisers, but though small in number, the number of occurrence of some of them is quite a big one. The most commonly used Koranic verse (With the exclusion of يا أيتها النفس followed sometimes by فادخلي في عبادي وادخلي جنتئة إرجعي إلى ربك راضية Koranic text. It occurred 24 times out of 37 Muslim obituaries in Ahram and 22 times out of 34 ones in the Rai, with two close percentages of occurrence, 64.86 and 64.70 successively. The almost identical frequency of occurrence leaves little doubt that there is no real discrepancy between Muslim obituaries in Ahram on the one hand and in Rai on the other hand. Other verses such as كل من عليها فان only occurred once and were hence dismissed as insignificant for the purpose of this research. Despite the fact that such instances are authentic, they are not representative and thus do not count in the comparison and contrast undertaken in this paper (See Table 6 in the appendix).

There are two Biblical verses in common use in the Christian obituaries under study. The first one is من آمن بي whhich occurs 9 times out of 13 in the Ahram Christian obituaries but only 3 times out of 16 in Rai, ( 69.23 percent and 18.75 successively). The second one is الرب أعطى و الرب أخذ (فليكن اسم الرب مباركا) which occurs only 3 times in Ahram Christian obituaries, with a percentage of occurrence as limited as 23.07, whereas the 
same verse occurs 12 times out of 16 in Rai Christian obituaries, with a percentage of occurrence as high as 75 (See Table 7 in the appendix).

\subsection{Implications \& Discussion}

The examination of the Biblical and Koranic verses used in the obituaries under study is additional evidence that the major differences exist mainly between Muslim and Christian obituaries in Ahram rather any other pair of sets. There is hardly any significant difference between the use of Koranic verses in Ahram and Rai. The difference appears in the use of Biblical verses, or more accurately, in the Biblical verse that is more common in Ahram Christian obituaries versus the one that is more common in Rai Christian death notes.

The common Biblical verse in Rai is الرب أعطى والرب أخذ (فليكن اسم الرب مباركا) which literally means that the Lord hath given; the Lord hath taken (Blessed be the name of the Lord). Biblical as it is, the reference (to Job), the notion and even the lexemes used in this verse could be as well typical of Islamic notions and even of Islamic religious terms. The verse is certainly Christian, yet it does cover a common ground between the two faiths: Islam and Christianity. In other words, it does not attract the attention of an average Muslim reader as non-Islamic and it definitely does not clash with any common belief among Muslims who form the religious majority in both communities, Egyptian and Jordanian alike.

When one looks at the common Biblical verse in Ahram obituaries one may easily spot the difference. The verse reads as follows: من آمن بي وإن مات فسيحيا which may be fairly translated as 'He who believeth in me shalt live even when he is dead'. The reference here is to Jesus Christ, the incarnated word of God in Christianity, Jesus Christ our Lord, God. So here again as in the case of the epistemic expression مع المسيح ذالك أفضل جدا Cof the emphis is on the controversial issue between Muslims and Christians; the nature of Jesus Christ. It would be an over simplification perhaps to ignore such recurrent evidence, then, that Christian obituaries in Ahram, and, hence Egyptian Christians may be deliberately trying to use a particular language register that sets them apart from the Other, in this case the Muslim majority in the society they are living in and of which they have always formed a part.

\section{Speculations \& Recommendations}

The starting point of this research is death notes and obituaries, yet the interest is certainly in life. As dear as our deceased ones are, the living still matter.

The research has pointed out the presence of a discrepancy between Christian and Muslim obituaries in Ahram only as representative of Egyptian press. The case is certainly different with reference to the Jordanian Rai newspaper where the similarities between Muslim and Christian obituaries range from 75 to 85 in their use of what the researcher regarded as deontic and or epistemic expressions.

Even in the use of Biblical verses, the Egyptian Christians have made it a point to display their difference from other Muslim Egyptians by opting the verse that would underline such a difference rather than another that yields itself to the general religious background and culture, whether consciously or unconsciously, of the whole society whose majority are Muslims,.

With the absence of the similarities between Christian and Muslim obituaries in the Jordanian Rai, there is little doubt left that the Egyptian Christians to say the least have a different approach and attitude from those adopted by their fellow Christians in Jordan.

A few questions thus arise: Why is that? Is this indicative of an unhealthy attitude? And, if so, where does it stem from? Finally what can be done about it?

May be the end of this research is rather unusual since it poses more questions rather than answers some. Yet it is bound to do so, as it is an attempt at exploring a multi-dimensional area. In fact, this paper may be fairly considered as one step among others to follow so as to be able to reach decisive conclusions. There is a need for another comparative/contrastive study of Christian Egyptian obituaries in the last week of, say, 1958 or even 1968 on the one hand, and the Christian obituaries in the sample of this study on the other hand (All were published in the last week of 2008). Such a study will either re-assert the findings of the present one, or prove them to be totally, or at least partly, invalid. If back in the late fifties and/or sixties of last century the same kind of deontic and epistemic expressions found in the 2008 obituaries were used by Egyptian Christians in their death notes, and if the same Biblical verse that is common in Christian obituaries in this study were common then, it would be fair to assume that the use of such expressions and verses is simply inherent as a characteristic feature of the language used by Egyptian Christians in general, regardless of any social, political and/or cultural changes that have taken place in Egyptian society since then. 
If, to the contrary, the Christian obituaries published in Ahram in the late fifties and/or sixties were closer to their Muslim counterparts, as the case is with the relation between Christian and Muslim obituaries now in the Jordanian Rai newspaper, then the discrepancy between the two sets of obituaries, the Christian versus the Muslim ones, depicted in this study is only the outcome of other social, political and cultural changes and is seriously indicative of a change in the attitude and behaviour of Egyptian Christians, a change that underlines a tendency to withdraw from the community and re-establish their own identity as a distinctive religious minority rather than an inseparable part of the Egyptian nation.

It was the researcher's deep concern regarding this possibility that has given rise to this research. And, it is the very same concern that makes the researcher hope that other researchers shall set out to further explore the issue, not only due to its possibly academic significance, but basically because of its undeniably vital importance on a practical level that touches upon our very being and identity as one nation where religion is unto God but our country is ours, all of us, regardless of colour, ethnic origin and/or religion.

\section{References}

Primary Sources:

Ahram Daily Newspaper, Egypt.

Rai Daily Newspaper, Jordan.

Secondary Sources:

Aarts, Bas. (1997). English Syntax and Argumentation. London: Macmillan Press LTD.

Abruzzi, Ray and J Michael. (ed) McGandy. (2003). Time: Religious and philosophical aspects. Encyclopedia of Science and Religion. Macmillan-Thomson Gale. eNotes.com. 2006. [Online] Available: http://www.enotes.com/science-religion-encyclopedia/time-religious-philosophical-aspects (9 Apr. 2008)

Bethan L. Davies and Andrew John Merrison. (2008). Getting stuff done: Institutional requests in UK higher education email. Sociolinguistics Symposium: Micro and macro Connections, 3-5 April 2008 Amsterdam, Book of Abstracts.

Bouma, Gary D and Clyne, Michael. (1995). Articulating religious meaning in conversation: Variations in linguistic style by subdenominational religious group. Review of Religious Research, Vol. 37, No. 2, pp. 132-146.

Connerton, Paul. (1989). How Societies Remember. UK: CUP.

Crystal, David. (1966). Language and religion, in L.Sheppard (ed.). Twentieth century Catholicism. (New York: Hawthorn Books). pp. 11-28

(1968). Linguistics, Language and Religion. Burns \& Oates/New York: Hawthorn Books.

Heizmann, Tanja. (2009). Acquisition of Deontic and Epistemic Readings of Must and Müssen. [Online] Available: http://www.people.umass.edu/tanjav/Heizmann UMOP34.pdf (13 Feb, 2009)

Lewis, Antony. (2007). WordWeb Pro 5.2. Wordnet database Copyright 2006 by Priceton University. Electronic Dictionary.

Lyons, John. (1995). Linguistic Semantics. Cambridge, CUP.

Merriam-Webster's $11^{\text {th }}$ Collegiate Dictionary. (2004). version 3.1 Electronic version.

Smith, Robert V. (1962). Analytical philosophy and religious/theological language. Journal of Bible and Religion, Vol. 30, No. 2, Apr., pp. 101-108.

\section{Notes}

Note 1. The term Deontic is an adjective that comes from the "Greek deont-, deon that which is obligatory, from neuter of present participle of dein to lack, be needful" (Merriam-Webster's 11 th Collegiate Dictionary, 2004) The term was first used as such in the field of linguistics in 1951, and is particularly used with reference to moral logic (WordWeb Pro 5.2, 2007).

Note 2. The term Epistemic is an adjective that was first used in the field of linguistics to refer to a type of modality in 1922, and comes from Greek epistm meaning knowledge, from epistanai to understand, know, from epi- + histanai to cause to stand (Merriam-Webster's $11^{\text {th }}$ Collegiate Dictionary, 2004). Thus, epistemic means of or relating to knowing, as epistemology is the study or a theory of the nature and grounds of knowledge especially with reference to its limits and validity. 
Note 3. The Function of modal verbs

Modal verbs (also known as helping verbs or auxiliary verbs) give additional information about the mood of the main verb that follows it. In other words, they help to incorporate or add the level of necessity: (must/need to/(have) got to/have to = obligation, requirement, no choice); (should/ought to = recommendation); (can/could = it is possible); and (may/might = option, choice).

Most modal verbs have two distinct interpretations, epistemic (معرفي) (expressing how certain the factual status of the embedded proposition is) and deontic) (انبغائي) involving notions of permission and obligation- (linguistics) (of a word or sentence) expressing duty).

Note 4. Merriam-Webster's $11^{\text {th }}$ Collegiate Dictionary, version 3.1 Electronic version, 2004

Table 1. Deontic Expressions in Muslim Obituaries

\begin{tabular}{|c|c|c|c|c|c|c|}
\hline No & Expression & & $\begin{array}{l}\text { hram } \\
\text { ccurrences- } \\
\text { entage }\end{array}$ & $\mathrm{N}$ & $\begin{array}{l}\text { Rai } \\
\text { ccurrences- } \\
\text { entage }\end{array}$ & $\begin{array}{l}\text { Percentage of } \\
\text { Difference }\end{array}$ \\
\hline 1 & 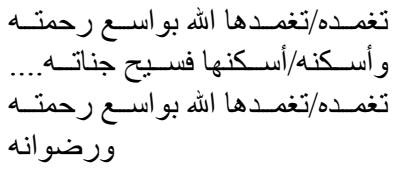 & 22 & $59.45 \%$ & 28 & $52.94 \%$ & $7 \%$ \\
\hline 2 & لا أراكــم الله مكروهــا فـي عزيــز & 11 & $29.72 \%$ & 8 & $23.52 \%$ & $6 \%$ \\
\hline
\end{tabular}

Table 2. Deontic Expressions in Christian Obituaries

\begin{tabular}{|c|c|c|c|c|c|c|}
\hline No & Expression & & $\begin{array}{l}\text { aram } \\
\text { ccurrences- } \\
\text { entage }\end{array}$ & & $\begin{array}{l}\text { Rai } \\
\text { ccurrences- } \\
\text { entage }\end{array}$ & $\begin{array}{l}\text { Percentag } \\
\text { e of } \\
\text { Difference }\end{array}$ \\
\hline 1 & 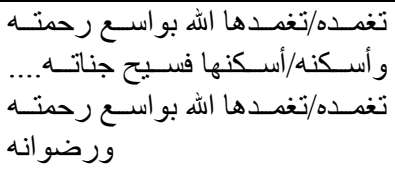 & 0 & $0.0 \%$ & 10 & $62.50 \%$ & $62.50 \%$ \\
\hline 2 & لا أر اكـــم الله مكرو هــا فـــ عزيــز & 0 & $0.0 \%$ & 5 & $31.25 \%$ & $31.25 \%$ \\
\hline
\end{tabular}

Table 3. Deontic Expressions in Ahram

\begin{tabular}{|c|c|c|c|c|c|c|}
\hline No & Expression & $\begin{array}{r}\text { Musl } \\
\text { No of } \\
P\end{array}$ & $\begin{array}{l}\text { ituaries- } \\
\text { trrences- } \\
\text { tage }\end{array}$ & $\begin{array}{l}\text { Chris } \\
\text { No o }\end{array}$ & $\begin{array}{l}\text { ituaries- } \\
\text { rences- } \\
\text { age }\end{array}$ & $\begin{array}{c}\text { Percentage of } \\
\text { Difference }\end{array}$ \\
\hline 1 & 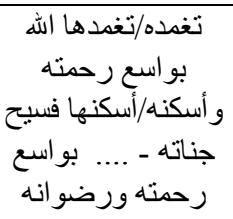 & 22 & $59.45 \%$ & 0 & $0.00 \%$ & $59.45 \%$ \\
\hline 2 & لا أر (عزم الله مكرو ها لديكم & 11 & $29.72 \%$ & 0 & $0.00 \%$ & $29.72 \%$ \\
\hline
\end{tabular}


Table 4. Deontic Expressions in Rai

\begin{tabular}{|c|c|c|c|c|c|c|}
\hline No & Expression & \multicolumn{2}{|c|}{$\begin{array}{c}\text { Muslim Obituaries- } \\
\text { No of Occurrences- } \\
\text { Percentage }\end{array}$} & \multicolumn{2}{|c|}{$\begin{array}{c}\text { Christian Obituaries- } \\
\text { No of Occurrences- } \\
\text { Percentage }\end{array}$} & $\begin{array}{c}\text { Percentage of } \\
\text { Difference }\end{array}$ \\
\hline 1 & 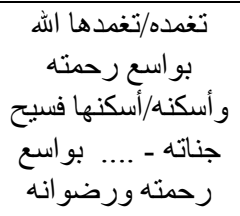 & 28 & $52.94 \%$ & 10 & $62.50 \%$ & $9.44 \%$ \\
\hline 2 & لا في (عزيز الهم لديكم هـا & 8 & $23.52 \%$ & 5 & $31.25 \%$ & $7.27 \%$ \\
\hline
\end{tabular}

Table 5. Epistemic Expressions in Ahram \& Rai

\begin{tabular}{|c|c|c|c|c|c|c|}
\hline No & Expression & \multicolumn{2}{|c|}{$\begin{array}{c}\text { Ahram } \\
\text { No of Occurrences- } \\
\text { Percentage }\end{array}$} & \multicolumn{2}{|r|}{ Rai } & $\begin{array}{l}\text { Percentage } \\
\text { of Difference }\end{array}$ \\
\hline \multirow[t]{3}{*}{1} & \multirow[t]{3}{*}{ نعي فاضل/ فاضلة } & Muslim 0 & $0.0 \%$ & 28 & $56 \%$ & \multirow[t]{3}{*}{$56 \%$} \\
\hline & & Christian 0 & $0.0 \%$ & 12 & $24 \%$ & \\
\hline & & Total 0 & $0.0 \%$ & 38 & $76 \%$ & \\
\hline \multirow[t]{3}{*}{2} & \multirow{3}{*}{ المغفور له بإذن الله } & Muslim 7 & $14 \%$ & 34 & $100 \%$ & \multirow[t]{3}{*}{$13.00 \%$} \\
\hline & & Christian 0 & $0.0 \%$ & 14 & $87 \%$ & \\
\hline & & Total 7 & $14 \%$ & 48 & $96 \%$ & \\
\hline \multirow[t]{3}{*}{3} & \multirow{3}{*}{ إنا لله و إنا إليه } & Muslim 19 & $51.35 \%$ & 4 & $12.00 \%$ & \multirow[t]{3}{*}{$12.00 \%$} \\
\hline & & Christian 0 & $0.0 \%$ & 0 & $0.0 \%$ & \\
\hline & & Total 19 & $51.35 \%$ & 4 & $12.00 \%$ & \\
\hline \multirow[t]{3}{*}{4} & \multirow{3}{*}{ رقد/رقدت على القيامة } & Muslim 0 & $0.0 \%$ & 0 & $0.0 \%$ & \multirow[t]{3}{*}{$56.25 \%$} \\
\hline & & Christian 2 & $15.38 \%$ & 9 & $56.25 \%$ & \\
\hline & & Total 2 & $15.38 \%$ & 9 & $56.25 \%$ & \\
\hline \multirow[t]{3}{*}{5} & \multirow{3}{*}{ الأنقل/انتقلت إلى السماوية } & Muslim 0 & $0.0 \%$ & 0 & $0.0 \%$ & \multirow[t]{3}{*}{$43.75 \%$} \\
\hline & & Christian 3 & $23.07 \%$ & 7 & $43.75 \%$ & \\
\hline & & Total 3 & $23.07 \%$ & 7 & $43.75 \%$ & \\
\hline \multirow[t]{3}{*}{6} & \multirow{3}{*}{ مع أفضل المسيح ذاكا } & Muslim 0 & $0.0 \%$ & 0 & $0.0 \%$ & \multirow[t]{3}{*}{$53.84 \%$} \\
\hline & & Christian 7 & $53.84 \%$ & 0 & $0.0 \%$ & \\
\hline & & Total 7 & $53.84 \%$ & 0 & $0.0 \%$ & \\
\hline
\end{tabular}

Table 6. Koranic Verses

\begin{tabular}{|c|c|c|c|c|c|c|}
\hline No & Verse & \multicolumn{2}{|c|}{$\begin{array}{c}\text { Ahram } \\
\text { No of } \\
\text { Occurrences- } \\
\text { Percentage } \\
\end{array}$} & \multicolumn{2}{|c|}{$\begin{array}{c}\text { Rai } \\
\text { No of } \\
\text { Occurrences- } \\
\text { Percentage }\end{array}$} & $\begin{array}{c}\text { Percentage of } \\
\text { difference }\end{array}$ \\
\hline 1 & إنا لله و إنا إليه راجعون & 19 & $51.35 \%$ & 4 & $12.00 \%$ & $39.35 \%$ \\
\hline 2 & مرضية إرجي إلى ربلى النفس المطمئنة. & 24 & $64.86 \%$ & 22 & $64.70 \%$ & $0.16 \%$ \\
\hline 3 & كل من عليها فان & 1 & $2.00 \%$ & 0 & $\% 0.0 \%$ & $2.00 \%$ \\
\hline
\end{tabular}


Table 7. Biblical Verses

\begin{tabular}{|c|c|c|c|c|c|c|}
\hline No & Verse & & $\begin{array}{l}\text { Iram } \\
\text { o of } \\
\text { rences- } \\
\text { entage }\end{array}$ & & $\begin{array}{l}\text { lai } \\
\text { o of } \\
\text { rences- } \\
\text { entage }\end{array}$ & $\begin{array}{c}\text { Percentage of } \\
\text { difference }\end{array}$ \\
\hline 1 & من آمن بي وإن مات & 9 & $69.23 \%$ & 3 & $18.75 \%$ & $50.52 \%$ \\
\hline 2 & (فليكن اسم الرب والرباركا) & 3 & $23.07 \%$ & 12 & $75.00 \%$ & $51.93 \%$ \\
\hline
\end{tabular}

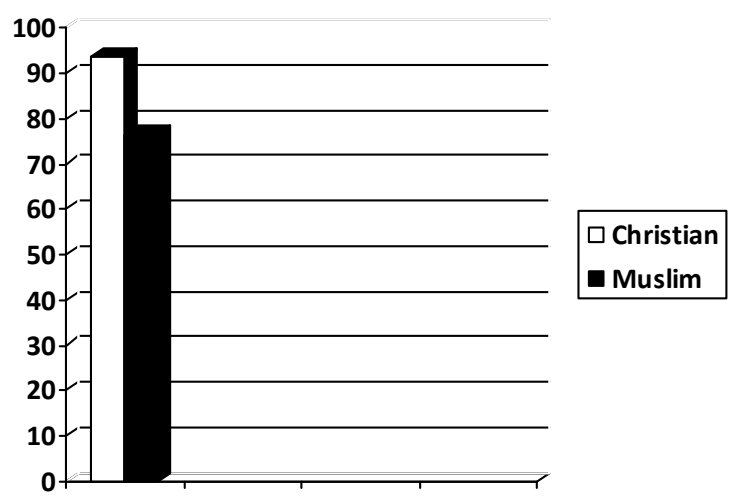

Figure 1. Deontic Expressions in Muslim \& Christian Obituaries-Rai

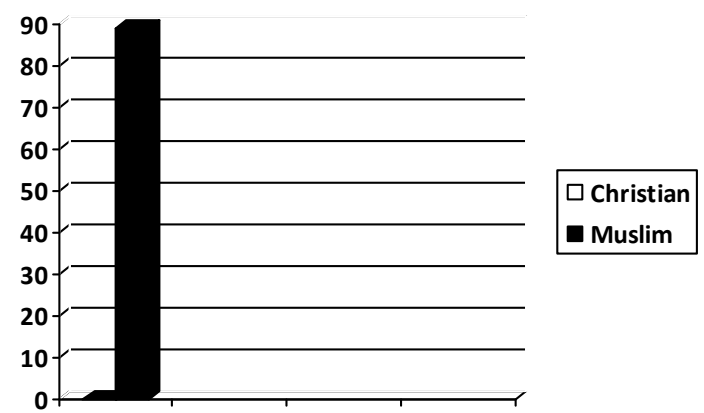

Figure 2. Deontic Expressions in Muslim \& Christian Obituaries- Ahram 


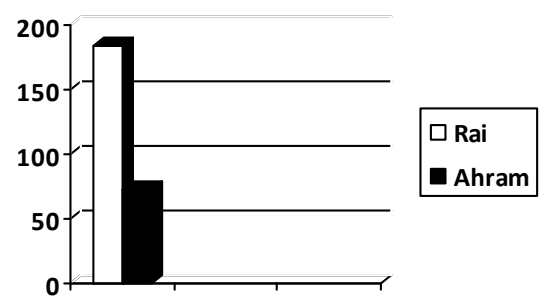

Figure 3. Ahram \& Rai Epistemic Expressions in Islamic Obituaries

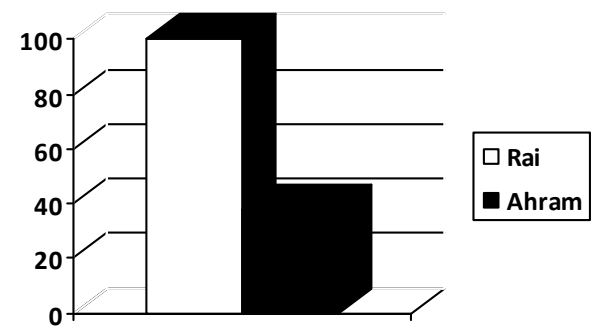

Figure 4. Ahram \& Rai Epistemic Expressions in Christian Obituaries

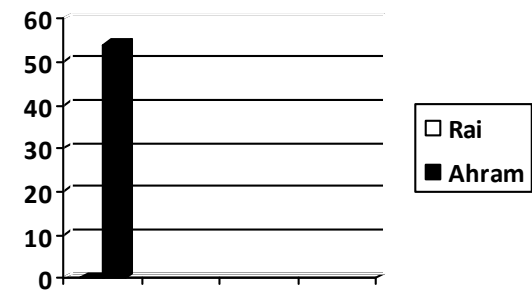

Figure 5. With Christ; it is much better (مع المسيح ذاك أفضل جدا) 